\title{
Induced Innovation in Clean Energy Technologies from Foreign Environmental Policy Stringency?*
}

\author{
Kyle S. Herman ${ }^{1 *}$ and Jun Xiang \\ 1 University College London, Global Governance Institute \\ * Correspondence: k.herman@ucl.ac.uk \\ *Final accepted version published in Technological Forecasting and Social Change
}

\begin{abstract}
In this paper, we re-conceptualize the meaning of policy-induced innovations in clean technologies by taking a cross-border approach. Previously, empirical research has shown how domestic climate and environmental policies induce firms in the same country to innovate in clean and environmental technologies. This phenomenon has become known as the Porter Hypothesis. However, most research focuses strictly on domestic inducement effects and, if foreign effects are accounted for, they are assumed to be either "knowledge" or "technology" spillovers. We, however, propose that policy spillovers might also induce innovations in other countries. In order to test this hypothesis, we construct a "foreign" environmental policy stringency proxy. This proxy is used as the main explanatory variable, with the outcome variable clean technologies, defined here as all renewable energy technologies as well as electrical energy storage, because these technologies are predominantly defined within the scope of climate and environmental policies as necessary to combat climate change and set forth as paramount to stemming pollutant causing climate change in the United Nations Framework Convention on Climate Change founding documents. Our results show that foreign environmental policy stringency does, indeed, induce clean-technology innovation at home, but this effect varies with different lag structures in our three models.
\end{abstract}

Keywords: dynamic innovation; ITC; cross-border climate policy; CCMTs; Environmental Technologies; Porter Hypothesis; UNFCCC; World Bank; ETS 


\section{Introduction and Background}

Clean energy technologies are central to global efforts to curb climate change and related emissions from conventional energy sources (Hoffert et al., 2002; Stern, 2006).

Innovation, diffusion, and deployment of new and effective clean technologies is critical to meeting the 2015 Paris Climate Agreement (Rogelj et al., 2016; Schmidt \& Sewerin, 2017). An important research avenue is policy-induced technological change for climate and clean technologies. This research can inform policy-makers as to the impacts of certain policies on technological innovation to meet the needs of climate change. Previous literature predominantly addresses induced technological change (ITC) in clean energy technologies in one of two ways: (1.) as demand-pull of the market for clean energies that in turn induces firms to innovate, (i.e. from policy that creates demand), or (2.) as technology-push, meaning innovation in technologies due to increasing returns to scale from innovative capacity of firms, (i.e. the innovation is induced by rapid technological change) (Ashford, 1985; Milliman \& Prince, 1989; Grubb, 2004; Hoppmann et al., 2013).

While the induced technological change literature conventionally rests on Hicks (1932), and later evolutionary growth theorists (such as Romer, 1990), the dual processes of innovation and diffusion in environmental technologies rely principally on the Porter Hypothesis $(\mathrm{PH})$, which proposes that environmental policy stringency can have positive innovation offsets in countries where that stringency is effective and occurs sooner than in other countries (Porter, 1991; Porter \& van der Linde, 1995; Lanoie et al., 2011). Three forms of the Porter Hypothesis are defined by Jaffe \& Palmer (1997): narrow, weak and strong. With ITC, the main concern is with the narrow version, which postulates that firms being regulated by environmental regulations will respond in a positive way by innovating and benefiting from new innovations, and thus becoming more competitive. In theory, this is considered a "win-win" for both policy-makers setting climate policies, as well as firms innovating and profiting from new clean technologies. Indeed, Lanoie et al. (2011), as well as Ambec et al. (2013) find strong evidence for these phenomena, even though in general the results hold for only the narrow version of the $\mathrm{PH}$. More interesting, however, is that the latter expose a gap in the literature concerning how cross-border climate-policy inducement effects transpire, even though they do not sufficiently examine this research question in great detail. As such, the question of how foreign environmental policies might induce domestic firms to innovate in environmental technologies is seldom approached in the empirical literature, but certainly marks an important research question especially considering the vast global diffusion of climate technologies (Dechezleprêtre et al., 2011; Nesta et al., 2014).

Lanjouw and Mody (1996) produce the seminal investigation of how environmental policy stringency impacts the rate of invention and diffusion of climate technologies. They also point towards the possibility of a "foreign" policy inducement effect upon domestic innovators (Popp, 2006). Most of the literature thereafter loosely follows their empirical strategy, which relies on patents as a signifier for innovation. For example, Jaffe and Palmer (1997) employ patenting in U.S. manufacturers to compare against foreign competitors, and find that, while Research and Development (R\&D) 
increases as a result of increases in regulatory stringency, patenting does not. Therefore, they find that innovation could have occurred, but the evidence is inconclusive. Newell (1997) also finds equivocal results using energy prices as a proxy for environmental regulations. While he does find that the direction of innovation is impacted, the rate of innovation is not induced by such regulations. Our research question here is somewhat different, however. We are interested in finding out if foreign environmental regulations have a cross-border inducement effect on domestic innovators. Thus while we are confined to the Porter Hypothesis in theory, which we interpret to be itself a theory grounded in global competitiveness dynamics, we also extend beyond this by asking the intriguing question of how environmental regulations are impacting the innovation of clean technologies across borders.

In this manner, we propose a dynamic version of the Porter Hypothesis, beyond the three that Jaffe and Palmer define (weak, narrow, strong). This approach rests on the strong assumption that environmental technologies are indeed actively traded across borders and that their innovative development is globally dispersed (Dechezleprêtre et al., 2008; Dechezleprêtre et al., 2011). This position also assumes high rates of diffusion among our sample of countries. Another strong assumption is that international actors can, indeed, send and receive environmental policy signals across borders (Dechezleprêtre et al., 2015). Such policy signals are here understood to be environmental policy spillovers, which extends beyond previous literature because the latter assumes only knowledge and technology spillovers are responsible for crossborder inducement effects in climate technologies (Verdolini \& Galeotti, 2011;

Constantini \& Crespi, 2008). This marks an important departure for clean technology policy and innovation research (Costantini et al., 2017).

Only a handful of other researchers explore the phenomenon of cross-border, policy induced innovation in clean energy technologies (Peters et al., 2012; Dechezleprêtre \& Glachant, 2014; Nesta et al., 2014; Groba, 2014). We will expound on their research investigations in detail below. The scant empirical research, beyond those listed immediately above, on a cross-border, dynamic Porter Hypothesis is indeed quite surprising. This is perplexing since, even as far back as the late 1970s, strong renewable energy policies in California induced innovation in Danish wind energy firms (Karnøe \& Garud, 2012); moreover California, with its stricter emission rules compared with the rest of the United States, was able to exert a strong influence on the car industry worldwide (Vogel, 1995). Thirdly Denmark, with its targeted promotion of energyefficient refrigerators, was able to prompt European suppliers to develop and offer such devices (Jänicke et al. 1999; Busch and Jorgens, 2005). Lastly, it is well known that Asian solar technologies currently dominate the world market even despite relatively weak market-oriented environmental policies in China, Japan and South Korea (meaning we can assume innovators were induced, in some way, by foreign environmental stringency) (Nykvist \& Nilsson, 2015). For these reasons, we find it neccesary to exlore in greater detail the foreign environmental policy inducement effects on innovators at home. 
The following section (2) provides a literature review of climate policy induced technological change and the effects of policies on cross-border inducement. Section (3) articulates our empirical approach and describes the variables to be deployed and specifies our three empirical models. Section (4) provides results and discussion. The final section (5) is the conclusion.

\section{Literature}

The Porter Hypothesis (PH) is employed as a theoretical foundation for this paper for several key reasons (Porter \& van der Linde, 1995). It is the first widely recognized theory able to account for positive innovative "offsets" induced by environmental regulations. Before the Porter Hypothesis (PH), it was largely assumed that such policies always negatively affected firm profits for the simple reason that the costs of compliance added otherwise additional costs for firm operations (Ambec et al., 2013). Likewise, prior to the $\mathrm{PH}$, it was assumed environmental policies inextricably limited firm competitiveness, both at home and abroad. However, the $\mathrm{PH}$ is slightly counterintuitive in that it proposes that environmental regulations can in fact induce firms to innovate in clean technologies. This is predicted because "by stimulating innovation, strict environmental regulations can actually enhance competitiveness" (Porter and van der Linde 1995: 98). In other words, the PH contends that firms could just as easily return additional profit despite, and indeed perhaps due to, increased environmental policy stringency. In this paper we would like to understand if this policy-inducement effect on firms might apply across borders.

A broad outgrowth of the PH is found in the literature on environmental technology innovation induced by environmental policy (Ambec \& Barla, 2006; Lanoie et al., 2011; Dechezleprêtre \& Sato, 2017). This literature attempts to open up the "black box" of environmental innovations (Jaffe et al., 2003). However, the black box still is not entirely opened to the idea that environmental policies induce foreign firms to innovate in clean technologies. While some seminal studies explore multiple countries (Lanjouw and Mody, 1996; Newell, 1997; Jaffe et al., 1997), these are limited by the fact that the countries under investigation (such as the U.S., Germany, and Japan, i.e. "the Royal Patent Family") are already considered the most "innovative", if patent data is employed (Branstetter, 2001). Thus, more thorough analysis needs to go further in exploring the global paradigm of environmental policy and clean technology development to include many other countries. Furthermore, in earlier research, only one or at most several environmental policies are considered. These types of studies therefore are seen as subscribing to the weak Porter Hypothesis (Jaffe \& Palmer, 1997). In contrast, the strong $\mathrm{PH}$ implies an investigation across multiple policies and countries. Indeed, many confirmatory tests of the weak version of the Porter Hypothesis already exist, for example: Popp, 2003; Johnstone, Haščič and Popp, 2010; Lanoie et al., 2011. This means the PH has accumulated empirical evidence, although there is still much research to be done. 
Lanoie et al. (2008) is one of the few studies to look at the PH weak and strong with a time-series model. Their findings are important because they expose the dynamics that exist across countries. In fact, the results of their paper provide the impetus for this current investigation. Indeed, Lanoie et al. first expose the idea of cross-border policy inducements in clean technologies using country-wide, firm-level survey data. This is followed by Dechezleprêtre et al. (2015) who conduct an empirical model of cross-border inducements constricted by regulatory distance between two countries. The latter find strong evidence of a cross-border effect. However, some of the strongest empirical results of these features, to date, are found in the automobile industry.

\section{Cross-Border Induced Technological Change in the Automobile Industry}

Foreign policy innovation inducements are explored by Haščič et al. (2008), Oltra and Saint Jean (2009), Lee et al. (2011), Gerard and Lave (2005), and Aghion et al. (2016). For example, the impact of U.S. regulation on automobile emissions and the rapid response of foreign car manufacturers is empirically shown in several papers (Pakes et al., 1993; Kerr \& Newell, 2003; Aghion et al., 2016). The most prominent and obvious case is the Japanese and German auto industry's response to U.S. environmental policy, including stricter emissions and the catalytic converter (Aghion et al., 2016). Yet, the responses are not restricted to only Germany and Japan; if it were only restricted to these two countries, we might be inclined to conclude that these induced innovations naturally arise out of the common factor of being the world's top three innovating countries. Indeed, the effects of foreign policy are felt in countries beyond Germany and Japan. For example, Medhi (2008) demonstrates the Korean response to U.S. and Japanese environmental policy in equipping their newly designed vehicles in anticipation of regulatory stringency (Ashford et al., 1979). This means Korean firms innovated ahead of the passage of stricter environmental policies set abroad, with the expectation that they could provide new technologies to emerging, stringent foreign policies. Indeed, classical innovation economists previously show how the premonition that regulations will soon change can prompt a technological search (Nelson \& Rosenberg, 1993). Presumably, multinational corporations such as car companies operating in different domestic environments, each composed of their own respective environmental regulations, are wise to develop new technologies suitably designed to meet emerging regulatory requirements in the various countries they operate in.

Interestingly in 1997, the year the UNFCCC's Kyoto Protocol is introduced, an abundance of new clean technologies are patented (Johnstone et al., 2010; Helm et al., 2014), signifying that the phenomena of anticipatory innovations indeed did occur for climate mitigation technologies. That firms not only respond to foreign environmental policies, but also respond ahead of such policies is quite remarkable, especially in countries outside the Royal Patent Family (so-named because nearly $70 \%$ of the top innovations are patented in Germany, U.S., and Japan). These general findings are confirmed by Lee et al. (2011) who find government intervention certainly impacts the pace of change in environmental technology partly due to firms' reactions to foreign 
environmental policies. Although anticipatory regulation is outside the scope of this paper, it is a promising area for future research on clean technology regulations.

Empirical Examinations of the foreign policy inducement effect Firms will only commit to protecting their intellectual property in foreign countries if indeed it is of commercial value for them to do so (Harhoff et al., 2003). It is therefore assumed that a patent filed in two or more jurisdictions represents a valuable, and indeed multinational, innovation outside of solely the domestic sphere (ibid). Dechezleprêtre and Glachant (2014) are among the first to assess the foreign policy inducement effects of wind technologies. They ask whether foreign or domestic environmental policies are more responsible for inducing innovation in wind technologies and find, surprisingly, that after controlling for the size of the foreign market for wind energy, the impact of foreign policies are twice as high as domestic policies. Certainly, this finding deserves further consideration, if only for the impact foreign policies might have on domestic clean technology innovations, as this impact has important ramifications for policy-makers.

Using a panel study across 15 OECD countries between 1978 and 2005, Peters et al. (2012) find domestic and foreign demand-pull policies indeed influence solar technology development. Interestingly, they find a much smaller effect for solar-PV as compared to the effect for wind technologies found by Dechezleprêtre and Glachant (2014), which is interesting as solar technologies are thought to be more geographically dispersed in terms of innovation (Groba, 2014). Moreover, Peters et al. find country-level innovation spillovers are almost entirely due to demand-pull policies in general (i.e. induced technological change) as opposed to technology-push (i.e. competition at the technological frontier is driving innovations).

Taken together, these two studies signify evidence of foreign induced technological innovation in clean energy technologies and, more specifically, the dynamic PH at work. However, taken separately, there remains one important physical difference between solar and wind technologies: solar technologies are much lighter (easier to transport) and relate closely to computer and ICT industries in terms of technological sophistication; meanwhile, wind technologies are normally much larger and locally customized to match local wind variations. Therefore it is slightly perplexing that Dechezleprêtre and Glachant find a very strong cross-border effect for wind, while Peters et al. find a much smaller cross-border inducement effect for solar technologies. Indeed, we would expect just the opposite. One explanation might be that Peters et al. (2012) employ a truncated time series in their analysis that only extends until 2005; meanwhile, global innovation and diffusion of solar energy technologies accelerates precipitously only after 2005 (Groba, 2014). We take note of the shortcomings of this truncated time-series and duly expand our sample well beyond 2005 in the empirical models below. 
From a more "global" perspective of policy inducement effects, Blind (2012) highlights the importance of laggard and leader environmental policy countries. With this conceptualization, lagging countries that take part in UNFCCC agreements are required to invest more money and resources to catch up to frontier members (frontier here refers to countries with the most stringent environmental policies). Yet, this is true only to the extent the "global" climate policies informed by the UNFCCC are legitimate and enforceable: "if the outcome of such international negotiations is more a minimal compromise the pressure to innovate will be reduced" (Blind, 2012: 10). This is particularly true for non-OECD countries, which is one reason we choose to include rather than leave out the BRICS in this present study. Most empirical analyses on the Porter Hypothesis and ITC are constrained to strictly OECD countries (Ambec \& Barla, 2006; Haščič et al., 2011), and therefore our models are more globally inclusive.

Finally, Groba (2014) examines a cross-border effect for solar technology components. He constructs an explicit gravity model for solar technology components induced by international policies. The results show the Porter Hypothesis holds, for smaller subsets of environmental technologies (such as solar energy technologies). Groba's sample is 21 OECD countries while he uses PPML estimation to analyze renewable energy policies and trade restrictions, and their consequences for solar component exports. The findings clearly demonstrate that, in countries that introduce stringent environmental policies earlier, solar innovations are supplied by both domestic and foreign innovators. This is direct empirical evidence of the dynamic Porter Hypothesis, operating across borders. In sum, we examine a large gap in the literature, contextually represented by the importance of international political economy regimes and the innovative development of clean energy technologies, which is not satisfactorily examined (Hall \& Helmers, 2010: 24). Thus, our focus on foreign inducement effects is not on knowledge spillovers but rather policy spillovers. This might also be conceptually approached as "foreign policypull" rather than domestic policy pull, or domestic technology-push. We also go beyond previous research by extending the analysis to BRICS (Brazil, Russia, India, China, South Africa), as well as 27 OECD countries, the latter predominantly explored in earlier research (De Vries and Withagen, 2005; Constantini and Crespi, 2008; Johnstone et al., 2010). Our main hypothesis is the following: foreign environmental policy stringency has a cross-border effect on innovators, such that innovating firms respond to foreign country environmental policies. 


\section{Data and Empirical Modelling Strategy}

Environmental policies change demand at home, and thus we should also expect foreign innovators to take note of increases to the stringency of environmental policies in foreign countries, if the firms are properly attuned to the innovative possibilities (Porter \& van der Linde, 1995). Coming closer to testing that hypothesis, Walz (2007) uses exports as a proxy for foreign regulation to understand how wind technologies react to foreign markets and policies. The findings suggest that exports in wind energy technology correlate with stringency of foreign environmental policy. Indeed, this is one of the strongest findings in the literature that foreign environmental policies indeed can induce domestic innovating firms.

Today, a fair amount of market-based environmental policies are understood to be inducing an equally large amount of point-of-source innovations in clean technologies (Johnstone et al., 2010; de Serres et al., 2010; Albrizio et al., 2014). In this paper we define clean technologies as renewable energy technologies (including all solar, wind, geothermal, hydro) as well as electrical energy storage technologies. The founding documents of the United Nations Framework Convention on Climate Change (UNFCCC), as well as many related policy documents, call for increased innovation in climate technologies, in particular point of source clean technologies such as renewable energy and storage technologies (Kütting \& Herman, 2018). Point-of-source innovations, such as clean energy rather than "end-of-pipe" scrubbers on smokestacks, are more easily diffused across national borders (Groba, 2014). Furthermore, the former are explicitly called for in the majority of domestic climate and environmental policies.

This impels the present investigation to take several key methodological departures from the literature. For example, even though other researchers employ energy prices as an inducement driver for clean tech innovation, we elect not to use this "statistically sound" (Popp, 2002) variable. First, energy prices are no longer seen as drivers of innovation in environmental technologies (Dechezleprêtre et al., 2011): energy prices have, since the early 2000s, largely been decoupled from environmental innovations, signaling that environmental innovations are now driven by policies rather than competing energies (ibid). While in the early 1990s conventional energy price increases correlated strongly with increases to innovation in clean technologies, this phenomenon no longer appears to exist (ibid). On the other side of the coin, energy price changes are now often the result of environmental policy, for example by making some energies either less or more expensive to conform with climate and emissions policies, rather than the effect (e.g. "feed-in-tariffs" for renewable energy). Therefore, energy prices are now largely unreliable as a main explanatory variable. Lastly, energy prices across countries are very difficult to compare (Dechezleprêtre \& Sato, 2014). Therefore, as the current analysis focuses on cross border impacts of environmental policies, we elect not to use energy prices as an environmental policy proxy.

Modelling Strategy and Research Question 
The models we construct are based upon a global political economy conceptualization of the dynamic version of the Porter Hypothesis. In other words, we explore certain individual technologies within the basket of clean technologies (narrow PH) while modelling inducement effects from abroad, and across different countries (both narrow and dynamic). Specifically, the research question is framed as the following: Does foreign environmental policy stringency induce innovation in clean energy technologies domestically?

To properly approach this question, we follow Lanoie et al. (2011) who find that environmental policy stringency induces innovations in the "eco-innovation chain" (Kanerva et al., 2009). We employ the OECD's Environmental Policy Stringency (EPS) (Botta \& Kozluk, 2014) as a proxy for environmental policy for two primary reasons: (1.) the EPS provides the longest time horizon; (2.) the EPS is almost exclusively focused on clean technology policies rather than the much more general environmental policies (the latter covered more generally by Yale's environmental performance index; see Hsu \& Zomer, 2014). In addition, the EPS has stood up to empirical testing for statistical consistency, both regarding similar indicators as well as balanced across countries (Botta \& Kozluk, 2014). We are, however, limited to the countries the OECD-EPS covers; although it does cover the BRICS, not all OECD countries are in fact accounted for. Susceptibility to data availability problems is not a unique problem in this research field (Knill et al., 2012). This limitation is acceptable, however, because most of the innovations come from OECD countries (Haščič et al., 2011).

\section{Theoretical underpinning}

We discuss the operationalization of these variables in detail below. The dependent variable is the innovation rate in clean energy technologies. The main explanatory variable is environmental policy stringency (EPS) in foreign countries, the effect of which is estimated conditional on all other controls, including domestic EPS. Another explanatory variable of interest is institutional quality because, without strong domestic institutions, foreign environmental policies are not expected to cause noticeable domestic inducement effects. Our approach is conceptually in line with the Aalborg theory of national innovation systems (Lundvall et al., 2001), with the caveat that knowledge-stock also play an important part in National Innovation Systems (NIS). As such, we assume each country's NIS follows a neo-Schumpeterian trajectory wherein home production responds to demands of the international market, and the importance of institutions factors prominently into home capacity to innovate. As such, we account for "absorptive capacity" via our knowledge-stock and institutional quality variables, as knowledge stock is seen as a good "proxy for local absorptive capacities" (Dechezleprêtre et al., 2015: 250).

Patents as a proxy of innovation 
Using patents as a dependent variable to explain rates and directions of innovation is widely accepted in innovation research. Patents have social value and are an economic indicator (Griliches, 1990). R\&D spillovers are prevalent in high technology sectors (Griliches, 1991), of which patents represent public knowledge. Environmental regulation (EPS) is shown to increase patenting in environmental technologies (Brunnermeier \& Cohen, 1998; de Vries \& Withagen, 2005; Popp, 2006; Johnstone, Haščič and Popp, 2008; Johnstone et al., 2010; Jaffe and Palmer, 1997; Lanjouw and Mody, 1996). An increase in innovation, proxied by patenting, is often the positive consequence of environmental regulations (Porter \& van der Linde, 1995). Indeed, the finding of positive innovation offsets in environmental technologies is central to the Porter Hypothesis. Due to the intrinsic value of patents this is interpreted to mean innovation occurs if patenting rates increase over time.

At the national level, patents represent a statistically sound way to measure a country's macroeconomic capabilities in terms of innovative change (Patel \& Pavitt, 1987; Griliches, 1990; Schmoch, 2008). A country's innovativeness is sometimes proxied by the breadth and depth of their patenting, controlled by strength of endogenous intellectual property protection. Despite some major drawbacks (Griliches, 1990; Cohen \& Levin, 1989; Dosi, 1988), patents remain among the best research metrics for determining policy-induced innovation (Rajamani, 2007; Abbot, 2008; Holdren, 2006; Mandel, 2005; Archibugi, 1992; Hagedoorn \& Cloodt, 2003). These data contain an enormous wealth of information and a "window into technical knowledge" (Christensen \& Raynor, 2013).

The patent data are collected from the OECD-stat website. The OECD uses an algorithm to extract data from the Worldwide Patent Statistical Database (PATSTAT) of the European Patent Office (EPO). As PATSTAT patents are considered the strongest for determining technological specialization (van Zeebroeck et al., 2006), extracting these data align well with our hypotheses here. International Patent Classification (IPC) symbols and simple keywords were used to identify relevant records in the databases. Furthermore, IPC symbols have the advantage of being language-independent and generally assigned to patent applications in a uniform manner across different countries (OECD, Patent Statistics Manual 2009).

The data extracted from the OECD can be conditioned to reflect the "priority date", which is the date of initial filing of the invention regardless of the family size, the latter discussed below. This is important for our present purposes since we may then adjust the lags and ensure uniformity across countries (Haščič \& Migotto, 2015). Priority date also shows inventive performance while accurately reflecting timing of patents, and due to these features is the most recommended way to carry out patent statistical analysis (Harhoff et al., 1999; Harhoff et al., 2003). Among other important information, patents also contain: (1) technical description of the invention (claims class; prior art; patent references); (2) development and ownership of the invention (list of inventors and location; applicant is inventor in the U.S.); and (3) history of the application 
(application/patent number; priority number; priority date; date of filing; date of publication; list of designation; date of refusal or withdrawal; date of grant) (OECD, Patent Statistics Manual 2009: 24).

Time lags of technological innovation for environmental technologies are found to average 2 years for domestic inducements (Lanjouw \& Mody, 1996). We hypothesize, in line with Nesta et al. (2014), that foreign inducements might take 3 or even 4 years, and therefore build our models accordingly (see also: Jaffe \& Palmer 1997; Constantini \& Crespi, 2013; Rubashkina et al., 2015). Lags in patenting are very important for understanding inducements for climate technologies, in particular "sudden changes in policy or carbon taxes, developments following upon major innovations, or in the exploitation of spillovers" (Weyant, 1999: 25), and factor as a very critical consideration in the construction of these types of models. The literature is clear on the specification of integrating well thought-out lag structures into environmental innovation models (Brunnermeier \& Cohen, 2003, Hamamoto, 2006; Johnstone et al., 2010; Popp et al., 2011; Weyant, 1999). Policies from abroad might have a longer inducement effect compared to domestic policies, because diffusion of policies across borders is expected to slow down the induced innovation response time (Nesta et al., 2014; Vona et al., 2012). This is particularly important when "institutional accommodation" (Nelson, 1993) presides over important latent variables, rendering more time needed for innovations to diffuse. Lastly, a very important benefit of the OECD data is its built-in patent family specifications. Patent families are patents filed in more than one jurisdiction, with greater patent families typically revealing a stronger global invention. In multiple country empirical models, it is critical to employ patent families of two or greater, as this ensures the invention is protected in multiple countries (Harhoff et al., 2003).

\section{Modelling specifications}

The sample includes 27 OECD countries and the 5 BRICS (Brazil, Russia, India, China, South Africa). These were selected on the basis that the Environmental Policy Stringency proxy provided by the OECD, which is employed to construct our main explanatory variable, covers all these countries and with sufficient time-series. Further, these countries actively participate in the UNFCCC and trade amongst each other, in line with our hypothesis that cross-border inducement effects occur. We regress innovation rates on environmental policy at home and abroad, high-technology exports, institutional quality, renewable energy output percentage, knowledge stock, and several control variables. Our analyses is embedded in the global political economy literature, and as such it is beyond the scope of this study to account for variations in competition across countries, bilateral trade agreements between countries, or product market regulation (PMR). Indeed, some of these more comprehensive econometric models are carried out in Nesta et al. (2014), Blind (2012), and most recently by Albrizio et al. (2017).

We construct a time-series, cross-sectional model. Our dependent variable, innovations in clean technologies, extends from 1998 until 2015, which is the latest year wherein patent data is available on the OECD statistics website. Meanwhile our explanatory 
variables, which are lagged two, three and four years, extend from 1996 until 2011. Our aim is to better understand rates of innovation in clean technologies over time, as these might be induced by foreign environmental policies. Our dependent variable, patents in clean technologies, extends to 2015 to account for an up to four-year time-lag of foreign policy inducing domestic innovation, a lag that is implicitly suggested by Jaffe and Plamer (1997) and Constantini and Crespi (2013), and explicitly mentioned in Rubashkina et al. (2015). The reasoning for this is that, for example, if foreign environmental policies are enacted in the year 2011, it may take four years to induce foreign innovators from policy to patent, the latter seeking patent protection for their innovation in the year 2015. This model is closer to a global political economy conceptualization of environmental innovation and diffusion than it is to evolutionary economics (see Rodrik, 2014 and Sovacool, 2016).

A reduced form equation specifies the model

\section{$Y \_i t=f\left(\sum E P S F \_j(t-x), E P S \_i(t-x), G O V \_i(t-x), Z \_(i(t-x))\right)$}

The dependent takes this specific form: $\quad \phi\left[Y_{-} t\right]_{-}$

Where $\phi$ represents the family (always family of 2 in our models here)

Where i represents domestic country (receiving foreign environmental policy stringency inducement)

Where $\mathrm{j}$ represents all other countries in sample

Where $x$ represents lag (between " 2 " and " 4 " years)

Where $t$ represents the year aligned with all other variables

Where $\mathrm{Y}$ represents CETs divided by all patents in country $\mathrm{i}$ year $\mathrm{t}$

Where $Y$ takes the log of the revealed technological advantage (RTA) form and represents innovation in clean energy technologies divided by total patents in country $i$, time $t$.

EPSf is environmental policy market stringency of all foreign countries, weighted by geographical distance measured by geographical distance between capital cities provided by CEPII Mayer and Zignago (2006).

EPS is environmental policy stringency in domestic (own) country $i$, time $t$

GOV is institutional quality, proxied by World-Bank Governance Indicators (Langbein \& Knack, 2010). We needed to take an average of the even years before the year 2000 since the World Bank does not provide the proxy for the years 1997 and 1999.

And $\mathrm{Z}$ represents a vector of country-specific control variables:

Knowledge Stock (cleantech patents with a decay rate over time)

Electricity Production from Renewable Energy, excluding large hydropower (as a $\%$ of total energy)

High-tech exports (as a \% of total exports)

Fossil Fuel Consumption (as a percentage of total energy consumption)

Research and Development per Gross Domestic Product

Kyoto Protocol (dummy variable)

Log Transformation of the Variables and RTA 
The dependent variable in the RTA form is employed by Sauvage (2014), Popp (2002) and Aghion et al. (2011), in several related cross-border environmental technology inducement models. The reason for RTA is to reveal a country's innovative rate of change in clean technologies over time, rather than simply an increase in the count of innovations in clean technologies over time (the latter might only suggest that total innovation in all technologies increased in the country, due largely to extraneous reasons). Apart from variables already provided as percentages, all the variables are transformed by taking the log in order to avoid spurious skews in the data, First, due to the variance in the countries covered in the data, in terms of their innovative capacity, the data do not provide smooth curves as needed for our statistical analysis. This is partially mitigated by the RTA form of the dependent variable. Further, following Peters et al. (2012), Greening et al., (2000); Constantini and Mazzanti (2012), we make use of a log-linear form that allows us, ex-poste, to understand the elasticities of innovations as an output regarding the multiple regression independent variables (Newell et al., 1999; Popp, 2006; Popp et al., 2011). This means we can interpret independent variable coefficients as percent increases or decreases, thus allowing the model output to provide elasticities as in Popp (2002).

\section{Explanation of the independent variables}

Our main explanatory variable of interest is foreign environmental policy stringency. The OECD breaks down its environmental policy stringency measure into market and non-market policies. Market-based policies, according to the OECD EPS, are feed-intariffs, carbon-trading schemes, and greenhouse gas emissions taxes; meanwhile, nonmarket policies are technology standards and government R\&D grants for renewable energy technologies (Albrizio et al., 2014; Botta \& Kozluk, 2014). We employ market environmental policy stringency as these are considered most conducive to inducing innovation in clean technologies (Johnstone et al., 2010; de Serres et al., 2010), even though equivocal results continue to exist in the empirical literature (Popp et al., 2010; Dasgupta et al., 2016; Schmidt \& Sewerin, 2017). In order to construct this variable, we first take the foreign policy of each foreign country in the sample, in each year, and divide by the geographical distance provided by CEPII (Head \& Mayer, 2002). Subsequently, we take an average of all these foreign policy proxies, for each year to arrive at a "foreign environmental policy stringency" for each country for each year (Gómez-Herrera, 2013). We are aware of the shortcomings of taking an "average" of foreign environmental policies in year $t$; however, in line with trade economy research, we aim to account for low variation by dividing by geographical distance before taking this average.

Institutions are critical to national innovation systems (North, 1990), not least because they allow knowledge to flourish, but also due to the role institutions play in maintaining economic order (Johnson, 1992; Freeman, 1992; Lundvall, 1992; Nelson, 1993; Kaufman et al., 2011). Evidently, institutional foundations are pivotal in formulating country's environmental performance objectives as well (Esty \& Porter, 
2005): countries would benefit environmentally from an emphasis on developing the rule of law, eliminating corruption, and strengthening their governance structures (ibid). Patenting also tends to follow from strong institutional capacity (Jensen et al., 2007; Teece, 1986). As such, models that employ patents as the dependent variable are well positioned to integrate institutional quality as a control variable. Our institutional quality proxy comes from the World Bank's worldwide governance indicators (Kaufman et al., 2011). Although there are some shortcomings of such proxies, for instance their low variation over time, we use government effectiveness as our institutional quality proxy.

Another important explanatory variable in this line of research is knowledge stock (Popp, 2002). Several different techniques for creating knowledge-stock exist in the literature, applicable to different aims of the models. For example, in their analysis of wind technology innovation, Ek and Soderholm (2010) construct knowledge stocks according to R\&D expenditures and take an annuity. For the present research, as we are concerned more with innovations than costs, we follow Verdolini and Galeotti (2011) by using the perpetual inventory method and taking a decay rate over time for clean technology patents, per country and according to patent family. The knowledge stock in each technology represents the technological competence of a country in the specified clean energy field; for that reason, it exposes parts of the national innovation system favorable towards creating new technologies in the same or related fields (Vona et al., 2012). This ensures that inducement effects and innovative output do not simply vanish in subsequent years, and also assumes knowledge builds upon past innovations (Caballero \& Jaffe, 1993; Nordhaus, 2002). As stated above, knowledge stocks are calculated using the perpetual inventory method, popularized by Peri (2005), and used explicitly for climate technologies by Popp (2002), Haščič and Johnstone (2011), Verdolni and Galeotti (2011) and Dechezleprêtre et al. (2013).

In similar vein, high technology exports and fossil fuel consumption (as a percentage of total energy consumption) are control variables in the models because these features play a particularly salient role in determining a country's propensity to export cleantech, and endogenous energy usage tendencies, respectively (Rodrik, 2014). It is expected that, since clean technologies are considered advanced technologies, high tech exports will be significant across the models. Separately, if fossil fuel consumption is increasing in a country over time, we do not expect that country to be innovating in clean technologies (thus we expect a negative sign). Several other control variables are added, in line with previous literature, including percentage of renewable energy (excluding large hydropower) and R\&D per GDP.

Following the environmental policy-induced innovation literature (Popp et al., 2011; Johnstone et al., 2010), a Kyoto Protocol dummy variable is created. This variable takes a "1" if the Kyoto Protocol is signed and ratified before July of that year and a zero otherwise (Johnstone et al., 2010). These data are found on the UNFCCC website. Once 
the dummy is changed to 1 , it is not changed back to zero. If the time series were structured so that the explanatory variables extended beyond 2012, countries such as Canada would have their Kyoto Dummy switched back to " 0 " because they formally withdrew from Kyoto after that time. We might also be inclined to change to " 0 " for Japan, New Zealand and Russia, as these countries did not commit to new targets after the first round. The United States signed but never ratified the Kyoto Protocol, so it always takes a " 0 " in our sample.

\section{Results and Discussion}

\section{Regression Results}

Three different models were tested using Stata (xi: xtreg, i.country fe). The models are constructed with Clean Energy Technologies (all renewable energy technology as well as electrical energy storage), with family of two (meaning the technology under examination is patented in two or more jurisdictions). The difference among the three models is the time lag of the explanatory variables, which is either $t-2, t-3$, or $t-4$ years. Such time lags are explicitly suggested in Rubashkina et al. (2015), and implicitly used in Jaffe and Palmer (1997) as well as Lanjouw and Mody (1997). Below in Table 1, we present our results. The dependent variable, revealed technological advantage in clean technologies, extends from 1998 until 2015, while the explanatory variables cover the years 1996-2011.

Table 1: The Determinants of the Innovation Rate in Clean Energy Technologies

\begin{tabular}{|l|c|c|c|}
\hline VARIABLES & $\begin{array}{l}\text { Cleantech lag 2 } \\
\text { years }\end{array}$ & $\begin{array}{l}\text { Cleantech lag 3 } \\
\text { years }\end{array}$ & $\begin{array}{l}\text { Cleantech lag 4 } \\
\text { years }\end{array}$ \\
\hline $\begin{array}{l}\text { Foreign } \\
\text { environmental } \\
\text { market-policies }\end{array}$ & $0.931^{* *}$ & $0.988^{* *}$ & $0.964^{* *}$ \\
\hline $\begin{array}{l}\text { Domestic } \\
\text { environmental } \\
\text { market-policies }\end{array}$ & $(0.379)$ & $(0.402)$ & $(0.431)$ \\
\hline & 0.008 & 0.066 & $0.157^{* * *}$ \\
\hline $\begin{array}{l}\text { qustitutional } \\
\text { Buality (World }\end{array}$ & $-0.572^{* * *}$ & $-0.536^{* * *}$ & $-0.423^{* *}$ \\
\hline
\end{tabular}




\begin{tabular}{|c|c|c|c|}
\hline & $(0.145)$ & $(0.154)$ & $(0.165)$ \\
\hline \multirow{2}{*}{$\begin{array}{l}\text { Knowledge } \\
\text { stock (clean } \\
\text { technology) }\end{array}$} & $0.238^{* * *}$ & $0.180^{* * *}$ & 0.075 \\
\hline & $(0.065)$ & $(0.069)$ & $(0.074)$ \\
\hline \multirow{2}{*}{$\begin{array}{l}\text { Electricity } \\
\text { production } \\
\text { from renewable } \\
\text { energy, } \\
\text { excluding hydro } \\
\text { (as a \% of total } \\
\text { energy) }\end{array}$} & $-0.143^{* * *}$ & $-0.125^{* * *}$ & -0.076 \\
\hline & $(0.044)$ & $(0.047)$ & $(0.050)$ \\
\hline \multirow{2}{*}{$\begin{array}{l}\text { High-tech } \\
\text { exports (as a \% } \\
\text { of total exports) }\end{array}$} & $0.053^{*}$ & $0.094^{* * *}$ & $0.069^{*}$ \\
\hline & $(0.032)$ & $(0.034)$ & $(0.036)$ \\
\hline \multirow{2}{*}{$\begin{array}{l}\text { Fossil fuel } \\
\text { consumption (as } \\
\text { a \% total energy } \\
\text { consumption) }\end{array}$} & $-0.422^{* * *}$ & $-0.354^{* * *}$ & $-0.303^{* *}$ \\
\hline & $(0.108)$ & $(0.115)$ & $(0.123)$ \\
\hline \multirow[t]{2}{*}{$R \& D$ per GDP } & -0.012 & -0.018 & 0.014 \\
\hline & $(0.022)$ & $(0.023)$ & $(0.025)$ \\
\hline \multirow[t]{2}{*}{ Kyoto dummy } & -0.092 & -0.050 & 0.117 \\
\hline & $(0.112)$ & (0.119) & $(0.127)$ \\
\hline
\end{tabular}




\begin{tabular}{|l|c|c|c|}
\hline Constant & 2.440 & 2.184 & 1.593 \\
\hline $\begin{array}{l}\text { Year fixed } \\
\text { effects }\end{array}$ & Yes & Yes & Yes \\
\hline $\begin{array}{l}\text { Number of } \\
\text { countries }\end{array}$ & 32 & 32 & 32 \\
\hline $\begin{array}{l}\text { Number of } \\
\text { observations }\end{array}$ & 512 & 512 & 512 \\
\hline R-squared & 0.491 & 0.367 & 0.216 \\
\hline
\end{tabular}

Standard errors in parentheses

*** $\mathrm{p}<0.01,{ }^{* *} \mathrm{p}<0.05,{ }^{*} \mathrm{p}<0.1$

\section{Summary of Key Findings}

Indeed, in line with Dechezlepretre and Glachant (2014), Nesta et al. (2014), Groba (2014), and to a lesser extent Peters et al. (2012), we found that foreign environmental policies are significant across all models (at 5 percent significance). Meanwhile, domestic environmental policies are significant in the third model at one percent. Our main explanatory variable, foreign environmental market policies, therefore, serves as an important explanation for rate of innovation in clean energy technologies. Institutional quality is highly significant across all models, suggesting that it is important for innovation in cleantech. Interestingly, however, this variable exhibits a negative coefficient. More research should be done to explore this finding, and it could very well be due to China supplying a great proportion of clean technologies, but still lacking in the World Bank's institutional quality proxy. Knowledge-stock is significant at the 1 percent level in the first and second models, and not at all in the third model with the dependent variable lag of four years. Electricity from renewable energy is significant up to $1 \%$ in the first two models and not at all in the third model; however, the coefficient has an unexpected negative sign. High technology exports, as a percentage of total exports, exhibits varying significance across all models $(10 \%, 1 \%$, and $10 \%$, respectively); this variable has the expected positive coefficient, since cleantech are closely related to high-tech innovations. Meanwhile fossil fuel consumption, as a percentage of total energy consumption, is significant in all three models. This variable has the expected negative sign since, as fossil fuel consumption goes up, we expect a country to innovate less in clean technologies. Our Kyoto dummy is not significant, which is at odds with some other empirical research. It might be important in future research to adjust the lag of this variable, since global agreements take time to induce national policies, which in turn induce innovations at home and abroad. 
Clean energy technologies are induced by both foreign and domestic environmental policy stringency, which previous literature addresses extensively but mostly constrained to domestic policy inducement effects (Constantini \& Crespi, 2009; Blind, 2012; Nicolli \& Vona, 2016). The results here are some of the first to empirically test a cross-border, Porter-like inducement for environmental technologies and, due in part to data constraints, this certainly warrants more research in the future. This finding is in line with Carraro et al. (2010), Popp et al. (2010), and more recently, Dasgupta et al. (2016), even though the latter largely attributes this effect to knowledge spillovers rather than foreign policy inducements.

The positive "knowledge stock" coefficients confirm what is found in previous literature on innovation systems, specifically that innovation is an "additive" effort (David, 1992; Caballero \& Jaffe, 1993). Countries and firms that have innovated in certain technology areas in the past are thus expected to continue innovating down similar trajectories (Acemoglu, 2002). This is evident in the significance of the hightechnology exports variable which always shows a positive coefficient and significant effect because advanced technologies are embodied in CETs. Overall, these findings are significant and empirically support the dynamic Porter Hypothesis. They show clean technologies are being innovated to partially meet foreign policy demand, the latter increasing as environmental policy stringency increases in foreign countries. Lastly, the implicit focus on lags is evidently very important for analysis of the Porter Hypothesis and may well have been overlooked in previous research (Lankoski, 2010; Ambec et al., 2013; Lanoie et al., 2008). More research should be done in this direction with focus on certain technologies, longer lag structures, and more concerted statistical analysis.

\section{Cautions and Limitations}

Some caution should be taken in interpreting the results of the dependent variable as a ratio (RTA). Despite the perceived benefits of using RTA to look at innovative differences across countries, there is a concern if too many zeros are found in the data (OECD, 2009), indicating that some countries lag far behind the frontier innovating countries. More robust models in this subject area are typically confined to only OECD countries. Similarly, in the case a country has zero patents in a certain CET sector during the year, we encountered a problem since we have taken the log of the ratio. For these reasons, we were forced to add " 1 " to the patent count in all countries and all sectors (to arrive at minimum one patent per year per technology and enabling us to then take the natural log of the dependent variable).

In addition, we were confronted by the central issue of cross-border measurement dissimilarities: adding an international dimension can increase the variation both across policies and across outcomes which, although sometimes providing for a richer sample, continues to be cause for concern especially when interpreting results. For example, European Nations maintain very low variation in environmental policies, while the addition of BRICS increased EPS variation across countries significantly. The high degree of convergence on several renewable energy policies in the EU, for example, and the slight divergence of other countries, could cause some modelling issues. We have 
attempted to mitigate the high variation in propensity to innovate among countries in our sample by constructing the dependent variable in RTA form, as the ratio controls for this variation (Malerba, 2004). Finally, the existence of patent data does not in fact imply that environmental innovations have been adopted (Popp 2012; Lanjouw et al. 1998), and therefore we must caution against treating rates of patenting as strictly implying that innovation has occurred. This is the million-dollar question separating commercialization of innovations and research into innovation, diffusion, and technological change.

\section{Conclusions}

We have thus established a connection between foreign environmental policy stringency and domestic innovation in clean technologies. Unlike the scant empirical investigations in previous research, confined mostly to OECD and domestic environmental policy inducement effects (De Vries and Withagen, 2005; Constantini and Crespi, 2008; Johnstone et al., 2010), we look at innovation induced from foreign environmental policy stringency. We therefore find some of the first empirical results of which we here refer to as a dynamic-narrow Porter Hypothesis. This dynamic approach accounts for the potential opportunity costs of environmental regulation and induced innovations. Our models closely resemble the Porter Hypothesis since the original conceptualization of the PH rests strongly on underlying features of trade theory and articulates how frontier policy countries might in fact benefit domestic and foreign innovators alike. Foreign EPS influence shows that the frontier stringent country does not suffer, in an innovative sense, because it induces more investment, FDI, and export into its country via novel environmental innovations. Later, policy stringent countries are able to export these technologies as other countries ratchet up their own domestic EPS. Likewise, this paper implies that frontier EPS countries may benefit by attracting foreign innovators which, in turn, increases the innovativeness of home clean-tech industries by incorporating a large variety of innovations from home and foreign markets. This is crucial to the maintenance and competitiveness of the national innovation system for environmental technologies.

The results of this paper are important for policy-makers for several reasons. First, and in line with previous literature following the Porter Hypothesis, properly crafted environmental policy appears to induce innovations in clean technologies. This is important because climate scientists implore decision-makers to continue to add clean and renewable technologies into our energy mix in order to properly combat some of the noxious impacts of conventional energy production. Policy-makers not only have the capacity to help induce more installations of emerging clean technologies, but also, they can induce more rapid innovation, and change the trajectories of innovation. The rates of innovation and diffusion of clean technologies can serve to either support or counteract the legacy of climate mitigation policies. Indeed, rapid innovation and diffusion of solar technologies throughout the world has, in the past several years, been pivotal in 
showing the promise that cleaner energy production is possible, and that policy can steer the conventional energy industry into a cleaner energy future.

A more novel output of this research, however, is that it shows how environmental policy changes don't merely impact domestic innovators. Strong policies also encourage foreign innovators, meaning that pioneer developed countries can drive the global clean-tech innovation frontier. In line with a dynamic Porter Hypothesis, our research results show that firms properly attuned to innovative possibilities, react to policy stringency both at home and abroad. Our empirical models find a more significant clean energy technology innovative inducement effect from foreign environmental market policies than domestic policies. Finally, some caution for policy-makers might follow: if the foreign inducement effect found here leads foreign innovators to vastly surpass and supplant domestic innovators (for example, some countries now import virtually all their solar energy components from East Asia), to the point where domestic innovators are no longer able to meet the climate technology needs specified by their domestic policies, serious ramifications for trade policy might ensue. For example, domestic firms and workers might seriously reconsider their support for climate policies if foreign firms and innovators are reaping the benefits of the clean energy technology transition, leading domestic governments to stymie the global diffusion of emerging clean technologies. Indeed, it is very interesting that, among the first trade tariffs and restrictions imposed by the Trump Administration were on solar technology imports from China. Therefore, climate and environmental policy-makers need to be keenly aware of the implications inherent in climate policies in coordination with industrial policies, as the former might become increasingly more intertwined with the latter in the coming decades.

Only a handful of other researchers attempt to empirically model the cross-border clean technology innovation inducement effect we explore here (Peters et al., 2012;

Dechezleprêtre \& Glachant, 2014; Nesta et al., 2014; Groba, 2014). As climate and environmental policies become ever-more global in scope, innovators appear willing and able to supply foreign markets with new clean technologies, even in the absence of stringent domestic environmental policies. Thus, this research question, and our results, can be of interest to policy-makers, whether these are practitioners in the domestic, regional or global realm. What we have shown here is that there is a foreign-policy inducement effect upon innovators in other countries, and that this effect might even be stronger than domestic environmental policies. It is a noteworthy finding because, if further research confirms our results, practitioners need to reassess their policy toolkits, as it appears from our research that innovation rates and trajectories of clean technologies could largely lie outside the scope of domestic policy-makers. 


\section{References}

Acemoglu, D. (2002). Directed technical change. Review of Economic Studies, 69: 781-809.

Aghion, P., Boulanger, J., \& Cohen, E. (2011). Rethinking industrial policy. Brussels: Bruegel.

Aghion, P., Dechezleprêtre, A., Hemous, D., Martin, R., \& Van Reenen, J. (2016). Carbon taxes, path dependency, and directed technical change: Evidence from the auto industry. Journal of Political Economy, 124(1), 1-51..

Albrizio, S., Botta, E., Koźluk, T., \& Zipperer, V. (2014). Do Environmental Policies Matter for Productivity Growth?. OECD Series.

Ambec, S., \& Barla, P. (2006). Can environmental regulations be good for business? An assessment of the Porter hypothesis. Energy studies review, 14(2).

Ambec, S., Cohen, M. A., Elgie, S., \& Lanoie, P. (2013). The Porter hypothesis at 20: can environmental regulation enhance innovation and competitiveness?. Review of environmental economics and policy, 7(1), 2-22.

Archibugi, D. (1992). Patenting as an indicator of technological innovation: a review. Science and public policy, 19(6), 357-368.

Arrow, K. (1962). Economic welfare and the allocation of resources or invention. In The rate and direction of inventive activity: Economic and social factors (pp. 609626). Princeton University Press.

Ashford, N. A., Ayers, C., \& Stone, R. F. (1985). Using regulation to change the market for innovation. Harv. Envtl. L. Rev., 9, 419.

Bentler, P. M., \& Chou, C. P. (1987). Practical issues in structural modeling. Sociological Methods \& Research, 16(1), 78-117.

Blind, K. (2012). The influence of regulations on innovation: A quantitative assessment for OECD countries. Research Policy, 41(2), 391-400.

Botta, E., \& Kozluk, T. (2014). Measuring environmental policy stringency in OECD countries: A composite index approach. OECD Economic Department Working Papers, (1177), 0_1.

Branstetter, L. G. (2001). Are knowledge spillovers international or intranational in scope?: Microeconometric evidence from the US and Japan. Journal of International Economics, 53(1), 53-79.

Braun, F. G., Schmidt-Ehmcke, J., \& Zloczysti, P. (2010). Innovative activity in wind and solar technology: Empirical evidence on knowledge spillovers using patent data. OECD

Brunel, C., \& Levinson, A. (2013). Measuring environmental regulatory stringency. OECD Trade and Environment Working Papers, 2013(5), 0_1.

Brunnermeier, S. B., \& Cohen, M. A. (2003). Determinants of environmental innovation in US manufacturing industries. Journal of environmental economics and management, 45(2), 278-293.

Caballero, R. J., \& Jaffe, A. B. (1993). How high are the giants' shoulders: An empirical 
assessment of knowledge spillovers and creative destruction in a model of economic growth. NBER macroeconomics annual, 8, 15-74.

Calel, R., \& Dechezlepretre, A. (2016). Environmental policy and directed technological change: evidence from the European carbon market. Review of economics and statistics, 98(1), 173-191.

Christensen, C., \& Raynor, M. (2013). The innovator's solution: Creating and sustaining successful growth. Harvard Business Review Press.

Cohen, W. M., \& Levinthal, D. A. (1990). Absorptive capacity: A new perspective on learning and innovation. Administrative science quarterly, 128-152.

Costantini, V., \& Crespi, F. (2008). Environmental regulation and the export dynamics of energy technologies. Ecological economics, 66(2), 447-460.Costantini, V., Crespi, F., Martini, C., \& Pennacchio, L. (2015). Demand-pull and technology-push public support for eco-innovation: The case of the biofuels sector. Research Policy, 44(3), 577-

595.Dasgupta, S., De Cian, E., \& Verdolini, E. (2016). The political economy of energy innovation. FEEM Working Paper.

David, P. A. (1992). Knowledge, property, and the system dynamics of technological change. The World Bank Economic Review, 6(suppl_1), 215-248.

De La Tour, A., Glachant, M., \& Ménière, Y. (2011). Innovation and international technology transfer: The case of the Chinese photovoltaic industry. Energy Policy, 39(2), 761-770.

Dechezleprêtre, A., \& Glachant, M. (2014). Does foreign environmental policy influence domestic innovation? Evidence from the wind industry. Environmental and Resource Economics, 58(3), 391-413.

Dechezleprêtre, A., \& Sato, M. (2017). The impacts of environmental regulations on competitiveness. Review of Environmental Economics and Policy, 11(2), 183-206.

Dechezleprêtre, A., Glachant, M., \& Ménière, Y. (2008). The Clean Development Mechanism and the international diffusion of technologies: An empirical study. Energy policy, 36(4), 1273-1283.

Dechezleprêtre, A., Glachant, M., Haščič, I., Johnstone, N., \& Ménière, Y. (2011). Invention and transfer of climate change-mitigation technologies: a global analysis. Review of environmental economics and policy, 5(1), 109-130.

De Serres, A., Murtin, F., \& Nicoletti, G. (2010). A framework for assessing green growth policies.

Dosi, G. (1984). Technical change and industrial transformation: the theory and an application to the semiconductor industry. Springer.

Dosi, G. (1988). Sources, procedures, and microeconomic effects of innovation. Journal of economic literature, 1120-1171.

Dosi, G., Pavitt, K., \& Soete, L. (1990). The economics of technical change and international trade. LEM Book Series. Easterly, W., \& Levine, R. (2001). What have we learned from a decade of empirical research on growth? It's Not Factor Accumulation: Stylized Facts and Growth Models. the world bank economic review, 15(2), 177-219.

Edquist, C. (1997). Systems of innovation: technologies, institutions, and organizations. 
Psychology Press.

Ek, K., \& Söderholm, P. (2010). The devil is in the details: Household electricity saving behavior and the role of information. Energy Policy, 38(3), 1578-1587. competitiveness and innovation. Global Environmental Change, 23(5), 902-913..

Freeman, C. (1992). Formal scientific and technical institutions in the national system of innovation. National systems of innovation: towards a theory of innovation and interactive learning, 169-187.

Furman, J. L., \& Hayes, R. (2004). Catching up or standing still?: National innovative productivity among 'follower' countries, 1978-1999. Research Policy, 33(9), 1329-1354.

Gerard, D., \& Lave, L. B. (2005). Implementing technology-forcing policies: The 1970 Clean Air Act Amendments and the introduction of advanced automotive emissions controls in the United States. Technological Forecasting and Social Change, 72(7), 761-778.

Gilpin, R., \& Gilpin, J. M. (2001). Global political economy: Understanding the international economic order. Princeton University Press.

Gómez-Herrera, E. (2013). Comparing alternative methods to estimate gravity models of bilateral trade. Empirical Economics, 44(3), 1087-1111.

Groba, F. (2014). Determinants of trade with solar energy technology components: evidence on the porter hypothesis?. Applied Economics, 46(5), 503-526.

Griliches, Z. (1979). Issues in assessing the contribution of research and development to productivity growth. The bell journal of economics, 92-116.

Griliches, Z. (1990). Patent statistics as economic indicators: a survey (No. w3301). National Bureau of Economic Research.

Griliches, Z. (1998). R\&D and productivity. National Bureau of Economic Research Books.

Grubb, M. (2004). Technology Innovation and Climate Change Policy: an overview of issues and options. Keio economic studies, 41(2), 103.

Hagedoorn, J., \& Cloodt, M. (2003). Measuring innovative performance: is there an advantage in using multiple indicators?. Research policy, 32(8), 1365-1379.

Hall, B. H., \& Ziedonis, R. H. (2001). The patent paradox revisited: an empirical study of patenting in the US semiconductor industry, 1979-1995. RAND Journal of Economics, 101-128.

Hamamoto, M. (2006). Environmental regulation and the productivity of Japanese manufacturing industries. Resource and energy economics, 28(4), 299-312.

Harhoff, D., Narin, F., Scherer, F. M., \& Vopel, K. (1999). Citation frequency and the value of patented inventions. The review of Economics and Statistics, 81(3), 511-515..

Harhoff, D., Scherer, F. M., \& Vopel, K. (2003). Citations, family size, opposition and the value of patent rights. Research policy, 32(8), 1343-1363.

Haščič, I., \& Johnstone, N. (2011). CDM and international technology transfer: empirical evidence on wind power. Climate Policy, 11(6), 1303-1314.

Haščič, I., \& Migotto, M. (2015). Measuring environmental innovation using patent 
data. OECD.

Haščič, I., de Vries, F. P., Johnstone, N., \& Medhi, N. (2008). Effects of environmental policy on the type of innovation: The case of automotive emissions control technologies. OECD.

Head, K., \& Mayer, T. (2002). Illusory border effects: Distance mismeasurement inflates estimates of home bias in trade (Vol. 1). Paris: CEPII.

Hekkert, M. P., Suurs, R. A., Negro, S. O., Kuhlmann, S., \& Smits, R. E. (2007).

Functions of innovation systems: A new approach for analysing technological change.

Technological forecasting and social change, 74(4), 413-432.

Helm, D. (2014). The European framework for energy and climate policies. Energy Policy, 64, 29-35.

Hicks, John. (1932 and I963). The Theory of Wages. London: Macmillan.

Hoppmann, J., Peters, M., Schneider, M., \& Hoffmann, V. H. (2013). The two faces of market support-How deployment policies affect technological exploration and exploitation in the solar photovoltaic industry. Research Policy, 42(4), 989-1003.

Hsu, A., \& Zomer, A. (2014). Environmental performance index. Wiley StatsRef: Statistics Reference Online, 1-5.

Jaffe, A. B. (1986). Technological opportunity and spillovers of R\&D: evidence from firms' patents, profits and market value. NBER

Jaffe, A. B., \& Palmer, K. (1997). Environmental regulation and innovation: a panel data study. The review of economics and statistics, 79(4), 610-619.

Jaffe, A. B., Newell, R. G., \& Stavins, R. N. (2003). Technological change and the environment. Handbook of environmental economics, 1, 461-516.

Jensen, M. B., Johnson, B., Lorenz, E., \& Lundvall, B. Å. (2007). Forms of knowledge and modes of innovation. The Learning Economy and the Economics of Hope, 155.

Johnson, B. H. (1992). Institutional learning. In Institutional Learning (pp. 23-44). Frances Pinter Publishers Ltd.

Johnstone, N., Haščič, I., \& Popp, D. (2008). Renewable energy policies and technological innovation: evidence based on patent counts (No w13760). National Bureau of Economic Research.

Johnstone, N., Haščič, I., \& Popp, D. (2010). Renewable energy policies and technological innovation: evidence based on patent counts. Environmental and resource economics, 45(1), 133-155.

Johnstone, N., I. Haščič and M. Kalamova (2010), Environmental Policy Design Characteristics and Technological Innovation: Evidence from Patent Data, OECD Environment Working Papers, No. 16, OECD Publishing. Doi:

0.1787/5kmjstwtqwhd-en

Kanerva, M. M., Arundel, A. V., \& Kemp, R. P. M. (2009). Environmental innovation: Using qualitative models to identify indicators for policy. Maastricht University.

Karnøe, P., \& Garud, R. (2012). Path creation: Co-creation of heterogeneous resources in the emergence of the Danish wind turbine cluster. European Planning Studies, 
20(5), 733-752.

Kaufmann, D., Kraay, A., \& Mastruzzi, M. (2011). The worldwide governance indicators: methodology and analytical issues. Hague Journal on the Rule of Law, 3(2), 220-246.

Kerr, S., \& Newell, R. G. (2003). Policy-Induced Technology Adoption: Evidence from the US Lead Phasedown. The Journal of Industrial Economics, 51(3), 317-343.

Kütting, G., \& Herman, K. (Eds.). (2018). Global environmental politics: concepts, theories and case studies. Routledge.

Langbein, L., \& Knack, S. (2010). The worldwide governance indicators: Six, one, or none?. The Journal of Development Studies, 46(2), 350-370.

Lanjouw, J. O., \& Mody, A. (1996). Innovation and the international diffusion of environmentally responsive technology. Research policy, 25(4), 549-571.

Lankoski, L. (2010). Linkages between environmental policy and competitiveness. OECD

Environment Working Papers, (13), 0_1.

Lanoie, P., Laurent-Lucchetti, J., Johnstone, N., \& Ambec, S. (2011). Environmental policy, innovation and performance: new insights on the Porter hypothesis. Journal of Economics \& Management Strategy, 20(3), 803-842.

Lanoie, P., Patry, M., \& Lajeunesse, R. (2008). Environmental regulation and productivity: testing the porter hypothesis. Journal of Productivity Analysis, 30(2), 121-128.

Lanoie, P., Patry, M., \& Lajeunesse, R. (2008). Environmental regulation and productivity: testing the porter hypothesis. Journal of Productivity Analysis, 30(2), 121-128. Chicago

Lee, J., Veloso, F. M., \& Hounshell, D. A. (2011). Linking induced technological change, and environmental regulation: Evidence from patenting in the US auto industry. Research policy, 40(9), 1240-1252.

Malerba, F. (Ed.). (2004). Sectoral systems of innovation: concepts, issues and analyses of six major sectors in Europe. Cambridge University Press.

Mayer, T., \& Zignago, S. (2006). GeoDist: the CEPII's distances and geographical database.

Medhi, N. (2008). Regulatory Matters: What Factors Matter in Regulating the Environment. Under Review in the Journal of Environment and Development.

Milliman, S. R., \& Prince, R. (1989). Firm incentives to promote technological change in pollution control. Journal of Environmental economics and Management, 17(3), 247-265.

Nelson, R. R. (Ed.). (1993). National innovation systems: a comparative analysis. Oxford university Press.

Nelson, R. R., \& Rosenberg, N. (1993). Technical innovation and national systems. National innovation systems: A comparative analysis, 1, 3-21.

Nesta, L., Vona, F., \& Nicolli, F. (2014). Environmental policies, competition and innovation in renewable energy. Journal of Environmental Economics and Management, 67(3), 396-411. 
Newell, R. G., Jaffe, A. B., \& Stavins, R. N. (1999). The induced innovation hypothesis and energy-saving technological change. The Quarterly Journal of Economics, 114(3), 941-975.

Nicolli, F., \& Vona, F. (2016). Heterogeneous policies, heterogeneous technologies: The case of renewable energy. Energy Economics, 56, 190-204.

Norberg-Bohm, V. (2000). Creating incentives for environmentally enhancing technological change: lessons from 30 years of US energy technology policy. Technological forecasting and social change, 65(2), 125-148.

Nordhaus, W. D. (2002). Modeling induced innovation in climate-change policy. Technological change and the environment, 9, 259-290.

Nykvist, B., \& Nilsson, M. (2015). Rapidly falling costs of battery packs for electric vehicles. Nature Climate Change, 5(4), 329-332.

Oltra, V., \& Saint Jean, M. (2009). Sectoral systems of environmental innovation: an application to the French automotive industry. Technological Forecasting and Social Change, 76(4), 567-583.

Organisation for Economic Co-operation and Development. (2009). OECD Patent Statistics Manual 2009. OECD.

Pakes, A., Berry, S., \& Levinsohn, J. A. (1993). Applications and limitations of some recent advances in empirical industrial organization: price indexes and the analysis of environmental change. The American Economic Review, 83(2), 240-246.

Pavitt, K. (1985). Patent statistics as indicators of innovative activities: possibilities and problems. Scientometrics, 7(1-2), 77-99.

Peri, G. (2005). Determinants of knowledge flows and their effect on innovation. Review of Economics and Statistics, 87(2), 308-322.

Peters, M., Schneider, M., Griesshaber, T., \& Hoffmann, V. H. (2012). The impact of technology-push and demand-pull policies on technical change-Does the locus of policies matter?. Research Policy, 41(8), 1296-1308.

Pizer, W. A., \& Popp, D. (2008). Endogenizing technological change: Matching empirical evidence to modeling needs. Energy Economics, 30(6), 2754-2770.

Popp, D. (2006). International innovation and diffusion of air pollution control technologies: the effects of NOX and SO2 regulation in the US, Japan, and Germany. Journal of Environmental Economics and Management, 51(1), 46-71.

Popp, D. (2011). International technology transfer, climate change, and the clean development mechanism. Review of Environmental Economics and Policy, 5(1), 131-152.

Popp, D., Haščič, I., \& Medhi, N. (2011). Technology and the diffusion of renewable energy. Energy Economics, 33(4), 648-662.

Popp, D., Newell, R. G., \& Jaffe, A. B. (2010). Energy, the environment, and technological change. Handbook of the Economics of Innovation, 2, 873-937.

Porter, M. E., \& Van der Linde, C. (1995). Toward a new conception of the environment-competitiveness relationship. The journal of economic perspectives, 9(4), 97-118. 
Rodrik, D. (2014). Green industrial policy. Oxford Review of Economic Policy, 30(3), 469491.

Rogelj, J., Den Elzen, M., Höhne, N., Fransen, T., Fekete, H., Winkler, H., ... \& Meinshausen, M. (2016). Paris Agreement climate proposals need a boost to keep warming well below 2 C. Nature, 534(7609), 631.

Rubashkina, Y., Galeotti, M., \& Verdolini, E. (2015). Environmental regulation and competitiveness: Empirical evidence on the Porter Hypothesis from European manufacturing sectors. Energy Policy, 83, 288-300.Schmidt, T. S., \& Sewerin, S. (2017). Technology as a driver of climate and energy politics. Nature Energy, 2(6), 17084.Sovacool, B. K. (2016). How long will it take?

Conceptualizing the temporal dynamics of energy transitions. Energy Research \& Social Science, 13, 202-215.Stern, N. (2006). What is the economics of climate change?. WORLD ECONOMICS-HENLEY ON THAMES-, 7(2), 1.

Taylor, M. R., Rubin, E. S., \& Hounshell, D. A. (2005). Regulation as the mother of innovation: The case of SO2 control. Law \& Policy, 27(2), 348-378.

Teece, D. J. (1986). Profiting from technological innovation: Implications for integration, collaboration, licensing and public policy. Research policy, 15(6), 285-305.

van Zeebroeck, N., van Pottelsberghe de la Potterie, B., \& Han, W. (2006). Issues in measuring the degree of technological specialisation with patent data. Scientometrics, 66(3), 481-492.

Verdolini, E., \& Galeotti, M. (2011). At home and abroad: An empirical analysis of innovation and diffusion in energy technologies. Journal of Environmental Economics and Management, 61(2), 119-134.

Vona, F., Nicolli, F., \& Nesta, L. (2012). Determinants of Renewable Energy Innovation: environmental policies vs. market regulation. Documents de Travail de l'OFCE, 5.

Walz, R. (2007). The role of regulation for sustainable infrastructure innovations: the case of wind energy. International Journal of Public Policy, 2(1-2), 57-88.

Weyant, J. P., \& Olavson, T. (1999). Issues in modeling induced technological change in energy, environmental, and climate policy. Environmental Modeling \& Assessment, 4(2-3), 67-85. 